RESEARCH ARTICLE - WASPS

\title{
The Cuticular Hydrocarbons Profiles in the Colonial Recognition of the Neotropical Eusocial Wasp, Mischocyttarus cassununga (Hymenoptera: Vespidae)
}

\author{
ASN MURAKAMI ${ }^{1}$, TM NUNES $^{2}$, IC DESUÓ ${ }^{1}$, SN SHIMA $^{1}$, S MATEUS $^{2}$ \\ 1 - Universidade Estadual Paulista, Rio Claro, SP, Brazil \\ 2 - Universidade de São Paulo, Ribeirão Preto, SP, Brazil
}

\author{
Article History \\ Edited by \\ Fabio S. do Nascimento, USP, Brazil \\ Received 01 September 2014 \\ Initial acceptance 23 October 2014 \\ Final acceptance 10 January 2015

\section{Keywords} \\ Recognition nestmate, Chemical signal, Colony, \\ Mischocyttarini.

\section{Corresponding author} \\ André Sunao Nishiuchi Murakami \\ Dep. de Zoologia, Instituto de Biociências, \\ Universidade Estadual Paulista \\ Campus de Rio Claro \\ Av. 24-A, n. 1515, Bela Vista \\ CEP: 13506-900, Rio Claro- SP, Brazil \\ E-Mail: sunamigobio@yahoo.com.br
}

\begin{abstract}
Cuticular hydrocarbons are chemical messengers with fundamental role in information transfer on the nestmate recognition, physical or behavioral caste, age, task specialization and reproductive status among individuals of colony. In basal (primitively) eusocial wasps, the role of cuticular hydrocarbons in the colonial recognition has been extensively studied in genus Polistes (Polistinae) and Stenogastrinae. Although the genus Mischocyttarus (Polistinae) is a large group of neotropical eusocial wasps and its cuticular hydrocarbons were only investigated in a few species. This study aimed to verify whether the cuticular hydrocarbons can discriminate the intercolonial identity in Mischocyttarus cassununga. Our results showed that the cuticular hydrocarbons potentially can play a role in intercolony recognition.
\end{abstract}

\section{Introduction}

Cuticular hydrocarbons (CHCs) are present on the surface of all insects and play an important role in the life of insects. These cuticular lipids have evolved for prevention of desiccation, as a barrier to microorganisms and as a important signals in the recognition system of social insects (Hadley, 1981; Lockey, 1988; Singer, 1998; Howard \& Blomquist, 2005). Each individual of a colony presents a blend of compounds on its cuticle that may carry information regarding its sex, age, caste, group task as well as colony (Howard \& Blomquist, 2005; Provost et al., 2008). These chemical messengers are determined by genetic (Ratnieks, 1991; Page et al., 1991; Arnold et al., 1996) and environmental components (Ratnieks, 1991; Gamboa, 1996).

Based on differences of cuticular compounds, individuals from the same colony are able to detect specific chemical signals in order to recognize the caste to which they belong as well as identify individually the nestmates, and differentiate the invaders (Gamboa, 1996; Lorenzi et al., 1997; Singer \& Espelie, 1997; Singer, 1998; Howard \& Blomquist, 2005; Richard \& Hunt, 2013). Studies on chemical signaling have shown that the profiles of cuticular hydrocarbons can be used in the recognition among nestmates due to its colonyspecific composition in ants (Bonavita-Cougourdan et al., 1987; Vander Meer et al., 1989; Wagner et al., 2000; Sturgis \& Gordon, 2011; Wilgenburg et al., 2011), bees (Breed \& Stiller, 1992; Breed et al., 1995; Breed et al., 1998; Dani et al., 2005; Nunes et al, 2008; Nunes et al, 2009; Nunes et al., 2011), wasps (Pfenning et al., 1983; BonavitaCourgoudan et al., 1991; Gamboa et al., 1996; Dani et al., 2001; Tannure-Nascimento et al., 2007; Bruschini et al., 2011; Mitra et al., 2014) and termites (Haverty \& Thorne, 1989; Bagnères et al., 1991; Kaib et al., 2002; Kaib et al., 2004. 
In independent founding wasps, cuticular hydrocarbons have been mainly studied in the subfamilies Polistinae (in Polistes) and Stenogastrinae. On the other hand, few studies have investigated the chemical communication in genus Ropalidia and Mischocyttarus. Studies show that the mechanism of recognition of conspecifics depends mainly on the amount of relative concentration of cuticular compounds in a colony. The colony specific composition, where females of a given colony are able to recognize their conspecifics by odour, was demonstrated in Polistes annularis (Espelie \& Hermann, 1990), in $P$. metricus (Espelie et al., 1990; Layton et al., 1994), in $P$. dominulus (Bonavita-Courgoudan et al., 1991; Dani et al., 2001; Pickett et al., 2000; Lorenzi et al., 2004; Sumana et al., 2005) , in P. fuscatus (Gamboa et al., 1996; Panek et al., 2001; Pfenning et al., 1983) in P. biglumis bimaculatus (Lorenzi et al., 1997), and P. satan (Tannure-Nascimento et al., 2007). In subfamily Stenogastrinae, individual recognition through a similar or homogeneous colony odour was also demonstrated in Liostenogaster flavolineata (Cervo et al., 1996; Cervo et al., 2002), in L. vechti (Cervo et al., 1996) Parischnogaster jacobsoni (Cervo et al., 1996) and Parischnogaster striatula (Zanetti et al., 2001). And more recently, in Ropalidia marginata has also demonstrated the importance of colonial profile of cuticular hydrocarbons (Mitra et al., 2014).

The tribe Mischocyttarini is a large group of eusocial wasps with about 245 described species (Carpenter, 1993; Silveira, 2008), however the cuticular hydrocarbons and their role in chemical communication of this group of social insects were investigated in a few species (Ferreira et al., 2012; Neves et al., 2012). Mischocyttarus cassununga is a species of neotropical wasp characterized by a linear and well stable dominance hierarchy, high longevity and rare replacement of the reproductive dominant female ("queen") in the colony (Murakami \& Shima, 2009; Murakami \& Shima, 2010). The aims of the present study were to verify whether intercolonial identity could be discriminated using the cuticular hydrocarbons.

\section{Material and Methods}

The research was realized at Universidade Estadual Paulista - UNESP, Campus of Rio Claro - SP, using eight (8) colonies of $M$. cassununga, during the post-emergence phase. All colonies were collected from the same population.

\section{Chemical analysis of the colonies}

After the collection of colonies, all female wasps were placed separately in glass vial $(1.5 \mathrm{ml})$ in freezer (temp. ca. $-20^{\circ} \mathrm{C}$ ) until the moment of the extraction of the cuticular compounds. The cuticular compounds of each sample were extracted by hexane (Labsynth) at $500 \mu 1$ for 1 minute. Each sample extract was analysed by gas chromatography coupled with mass spectrometry (SHIMADZU, model QP2010, Tokyo, Japan), equipped with a ZB-5MS column; length: $30 \mathrm{~m}$; ID: $0.25 \mathrm{~mm}$; film thickness: $0.25 \mu \mathrm{m}$. The column was initially set at $150{ }^{\circ} \mathrm{C}$ for $3 \mathrm{~min}$, then programmed at a rate of $3{ }^{\circ} \mathrm{C} / \mathrm{min}$ to $280^{\circ} \mathrm{C}$, and then held at $280^{\circ} \mathrm{C}$ for $15 \mathrm{~min}$. The carrier gas was helium at a flow rate of $1 \mathrm{ml} / \mathrm{min}$. The injection mode was splitless and the injection temperature was $250{ }^{\circ} \mathrm{C}$. For the identification of the cuticular compounds it was performed comparisons of mass spectra with the Wiley library and with the data of the diagnostic ions present in the literature. All the process of the hydrocarbons identification was carried out with the aid of the program GCMS solutions for Windows (Shimadzu Corporation).

\section{Statistical analysis}

Statistical analyses were conducted in Statistica 7.0 for Windows (StatSoft Inc., Tulsa, OK, U.S.A.). The concentration of all compounds was transformed according to Reyment's formula $\left(Z=\ln \left(A_{p} / g\left(A_{p}\right)\right)\right)$, where $A_{p}$ is the peak area, $g\left(A_{p}\right)$ is the geometric mean of the peak in each group of females and $\mathrm{Z}$ is the transformed area of the peak (AITCHISON, 1986). Compounds that, on average, contributed less than $1 \%$ to the overall chemical profile (i.e. linear alkanes, monomethyl and dimethyl alkanes) were excluded from the analysis, as made by Kather et al. (2011). The areas of these peaks were recalculated, taking into account the reduced data set, and then reanalysed by statistical tests. First, a one-way ANOVA was carried out to test for group differences (colonies) in total compound quantity for each chemical compound. At the same time, a two-way MANOVA with Pillai test and posthoc Tukey test was used to test for group differences for each chemical compound separately.

\section{Results and Discussion}

The analysis of cuticular compounds of Mischocyttarus cassununga resulted in a total of 88 peaks detected, divided into linear alkanes, methyl-branched alkanes and dimethylbranched alkanes, with chains between 16 and 36 carbon atoms. The selected peaks for chemical analysis are indicated in figure 1. The overall composition of hydrocarbons on an insect's cuticle, termed as the profile, can range from highly complex to relatively simple (Dani et al., 2001). For example, in the genus Polistes, the most studied group of basal eusocial wasp, the species Polistes biglumis bimaculatus (Lorenzi et al., 1997) and P. dominulus (Dapporto et al., 2004) have respectively 63 and 65 cuticular compounds, while $P$. metricus (Layton et al., 1994) and P. satan (Tannure-Nascimento et al., 2007) have cuticular compounds 25 and 28, respectively.

The objective of determining whether the entire mixture of cuticular compounds or some specific compounds are important for individual discrimination has generated discussion. However, there are evidences that linear alkanes are not involved in recognition processes. Studies suggest that linear alkanes are relatively less colony-specific than the branched alkanes and other compounds present in the cuticle (Gamboa et al., 


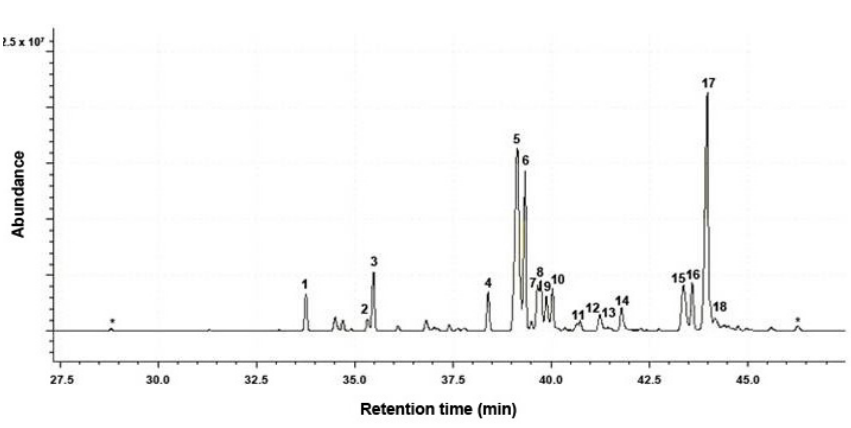

Fig 1. Total ion mass chromatograms of a Mischocyttarus cassununga female wasp. Peak numbers from 1 to 18 correspond to the selected compounds that contributed more than $1 \%$ to the overall chemical profile. $1=\mathrm{C} 27,2=7,16-\mathrm{DiMeC} 27,3=3-\mathrm{meC} 27,4=\mathrm{C} 29,5=15-, 13-, 11-, 9-\mathrm{MeC} 29$, $6=7-\mathrm{MeC} 29,7=11,15-\mathrm{DiMeC} 29,8=9,15+9,16-\mathrm{DiMeC} 29,9=7,15+$ 7,18-DiMeC29, 10= 3-MeC29, 11= 13,15-DiMeC29, 12= 15-,14-,13-,11$\mathrm{MeC} 30,13=11,15-\mathrm{DiMeC} 30,14=15-, 13-, 11-, 9-\mathrm{MeC} 31$, 15= 7-MeC31, 16=11,16-DiMeC31, 17=9,21-DiMeC31 and 18=7,19+7,16-DiMeC31. Asterisks represent identified contaminants in some of the samples.

1996; Dani et al., 2001; Dani et al., 2005). In honeybees, the alkenes or unsaturated fatty acids seem to influence more in the colonial recognition than the alkanes and unsaturated fatty acids (Breed, 1998; Breed et al., 1998). Dani et al. (2005) similarly showed that linear alkanes have no effect on recognition in honeybee, in which only branched alkanes and alkenes are found. According to a comparative study of cuticular hydrocarbons of 78 species of 5 subfamilies of ants, the wide diversity of dimethylalkanes can indicate them as excellent compounds discriminatory recognition interand intra-specific species (Martin \& Drijfhout, 2009). Dani et al. (2001) tested the effect of the concentration of some cuticular substances during the process of recognition between conspecific of Polistes dominulus (Vespidae), and found that linear alkanes did not cause any effect on the recognition response, unlike methylalkanes and alkenes. In the same species ( $P$. dominulus), Lorenzi et al. (2004) found that total quantities of CHCs increased after emergence, with branched alkanes increasing drastically when compared with other classes of hydrocarbons. Older wasps did not incorporate hydrocarbons, suggesting that the chemical profiles of mature wasps are less prone to chemical shifts than those of newly emerged wasps. In stingless bees, newly emerged workers have a very simple hydrocarbon pattern on their cuticle consisting almost entirely of linear alkanes (mainly C23; C25; C27 and C29) and guards were not able to discriminate between newly emerged nestmates and non-nestmates (Nunes et al., 2011). In M. cassununga, all colonies significantly differed according to total quantity of fourteen cuticular hydrocarbons (=eight peaks) (Table 1 and Figure 2). The branched alkanes were the predominant compounds in the chemical differentiation of individuals. Differently, in $P$. satan (Vespidae), the linear alkanes were the main compounds responsibles by the differentiation of individuals through the colonial profile (Tannure-Nascimento et al., 2007; 2008).
Table 1. Group differences (colony) in total compound quantity for each chemical compound during the post-emergence phase in $M$. cassununga.

\begin{tabular}{|c|c|c|c|c|c|}
\hline N. & Cuticular compound & DF & SS & F statistic & p-value \\
\hline 1 & $\mathrm{C} 27$ & 7 & 58.57 & 3.97 & $<0.01$ \\
\hline 2 & 7,16-dimeC27 & 7 & 29.82 & 0.92 & 0.49 \\
\hline 3 & 3-meC27 & 7 & 29.22 & 6.54 & $<0.001$ \\
\hline 4 & $\mathrm{C} 29$ & 7 & 33.82 & 3.55 & $<0.01$ \\
\hline 5 & 15-,13-,11-,9-meC29 & 7 & 6.39 & 4.30 & $<0.001$ \\
\hline 6 & 7-meC29 & 7 & 17.20 & 2.85 & 0.01 \\
\hline 7 & 11,15-dimeC29 & 7 & 5.99 & 0.49 & 0.83 \\
\hline 8 & $9,15+9,16$-dimeC29 & 7 & 14.11 & 0.88 & 0.52 \\
\hline 9 & 7,15 + 7,18-dimeC29 & 7 & 93.09 & 2.46 & 0.02 \\
\hline 10 & 3-meC29 & 7 & 21.03 & 1.23 & 0.30 \\
\hline 11 & 13,15-dimeC29 & 7 & 75.53 & 15.07 & $<0.001$ \\
\hline 12 & $15-, 14-, 13-, 11-\mathrm{meC} 30$ & 7 & 33.11 & 5.42 & $<0.001$ \\
\hline 13 & 11,15-dimeC30 & 7 & 2.63 & 1.34 & 0.25 \\
\hline 14 & 15-,13-,11-,9-meC31 & 7 & 19.33 & 2.39 & 0.03 \\
\hline 15 & 7-meC31 & 7 & 15.72 & 3.80 & $<0.01$ \\
\hline 16 & 11,16-dimeC31 & 7 & 13.09 & 10.42 & $<0.001$ \\
\hline 17 & 9,21-dimeC31 & 7 & 101.24 & 2.82 & 0.01 \\
\hline 18 & 7,19+7,16-dimeC31 & 7 & 15.07 & 0.94 & 0.32 \\
\hline
\end{tabular}

$\mathrm{N}=$ number. $($ ANOVA: $\mathrm{p}$ was significant for $<0.01$ and $<0.001)$.

MANOVA test also showed that the overall chemical profiles of cuticular hydrocarbons are significantly different among colonies (MANOVA: $\mathrm{F}=2.61$, d.f. $=315,105, \mathrm{p}$ $<0.001$, Pillai). A further analysis using Tukey multiple comparison test $(p<0.001)$ shows the significant differences for each chemical compound separately (Table 2). The peaks of the cuticular hydrocarbons 13,15-DiMeC29 and 11,16-DiMeC31 were the chemical compounds with significant differences in relative abundance among the higher number of colony groups (in eleven comparisons for both). Colonies also differed significantly in the peaks 3-MeC27 (in five comparisons), 15-,14-,13-,11-MeC30 (in four comparisons), C29 (in two comparisons), 15-,13-,11-,9-MeC29 (in two comparisons), 7-MeC31 (in two comparisons) and C27 (in one comparisons). These results probably indicate that colonial recognition also occurs through the cuticular hydrocarbon profile in this neotropical species of social wasp(Subfamily Polistinae-genus Mischocyttarus). Several studies on cuticular hydrocarbons show that differences on chemical profiles can be used as cues for nestmate recognition in Polistinae (Polistes and Ropalidia) and Stenogastrinae (Pfenning et al., 1983; Cervo et al., 1996; Lorenzi et al., 1997; Dani et al., 2001; Zanetti et al., 2001; Cervo et al., 2002; Mitra et al., 2014). 


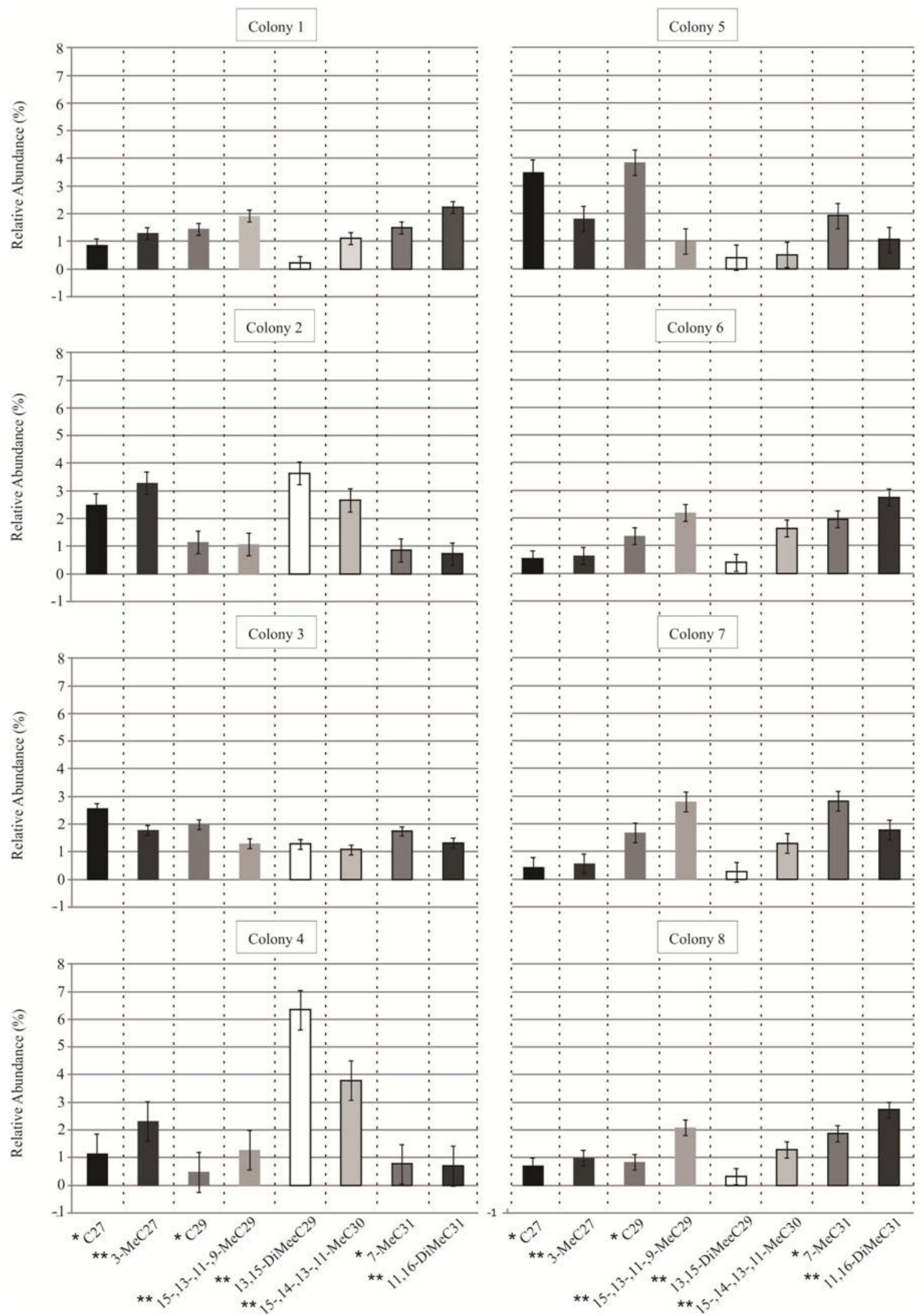

Fig 2. Relative abundance of the chemical compounds in the colonies of $M$. cassununga. C27; 3-MeC27; C29; 15-, 13, 11, 9-MeC29; 13, 15-DiMeC29; 15-, 14-, 13-, 11-MeC30; 7-MeC31 and 11, 16-DiMeC31. Error bars are standard errors. (ANOVA: $\mathrm{p}<0.01 * ; \mathrm{p}<0.001 * *)$. 
Table 2. Comparisons between colony groups with significant differences according to the cuticular compounds in M. cassununga. C: colony.

\begin{tabular}{|c|c|}
\hline Compounds & $\begin{array}{l}\text { Comparisons among colony groups } \\
\text { with significant differences }\end{array}$ \\
\hline $\mathrm{C} 27$ & $\mathrm{C} 5 \times \mathrm{C} 7$ \\
\hline 3-MeC27 & $\begin{array}{l}\text { C } 2 \times C 6 ; \text { C } 2 \times C 7 ; \text { C } 2 \times C 8 ; \\
\text { C } 4 \times C 6 ; C 2 \times C 6\end{array}$ \\
\hline $\mathrm{C} 29$ & $\mathrm{C} 4 \times \mathrm{C} 5 ; \mathrm{C} 5 \times \mathrm{C} 8$ \\
\hline 15-,13-,11-,9-МеС29 & $\mathrm{C} 2 \times \mathrm{C} 7 ; \mathrm{C} 5 \times \mathrm{C} 7$ \\
\hline 13,15-DiMeC29 & $\begin{array}{l}\text { C } 1 \times C 2 ; C 1 \times C 4 ; C 2 \times C 5 ; \\
\text { C } 2 \times C 6 ; C 2 \times C 7 ; C 2 \times C 8 ; \\
\text { C } 3 \times C 4 ; C 4 \times C 5 ; C 4 \times C 6 ; \\
\text { C } 4 \times C 7 ; C 4 \times C 8\end{array}$ \\
\hline 15-,14-,13-,11-МeC30 & $\begin{array}{l}\text { C } 2 \times \mathrm{C} 3 ; \mathrm{C} 2 \times \mathrm{C} 5 ; \mathrm{C} 3 \times \mathrm{C} 4 \\
\mathrm{C} 4 \times \mathrm{C} 5\end{array}$ \\
\hline 7-MeC31 & $\mathrm{C} 4 \times \mathrm{C} 5 ; \mathrm{C} 4 \times \mathrm{C} 7$ \\
\hline 11,16-DiMeC31 & 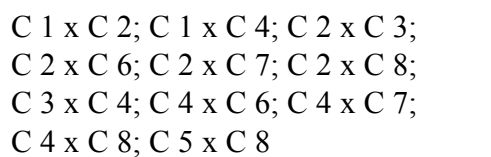 \\
\hline
\end{tabular}

(Tukey multiple comparison test, $\mathrm{p}<0.001$ ).

Despite the ability of colonial recognition has been studied for a long time, this aspect was not much investigated in the endemic species from the South America. In the neotropical species Polistes satan, a variation in hydrocarbon profile was sufficiently strong to discriminate individuals according to their colony membership. According to this study, it seems that small differences in the proportion of these compounds can be detected and used as a chemical-based cue by nestmates to detect invaders and avoid usurpation (Tannure-Nascimento et al., 2007). The hydrocarbon analysis in M. cassununga shows that the differentiation of the cuticular profile among colonies is related to differences in abundance of a mixture of compounds, especially of branched alkanes. Although we did not perform bioassays in this study, field observations show that female wasps are aggressive toward non conspecific individuals. This fact also may indicate that these wasps are capable to use these chemical differences for recognition.

In conclusion, this work in M. cassununga represents a initial investigation of the potential role of cuticular hydrocarbons as mediators of nestmate recognition in the Mischocyttarini tribe. However, more researches are necessary toward a better understanding of the importance of cuticular hydrocarbons in Neotropical social wasps.

\section{Acknowledgments}

Thanks to partnership with Faculdade de Ciências Farmacêuticas (Universidade de São Paulo - USP, Ribeirão Preto - SP). Funding was provided by the Capes (Coordenação de Aperfeiçoamento de Pessoal de Nível Superior).

\section{References}

Aitchison, J. (1986). The statistical analysis of compositional data. London: Chapman \& Hall

Arnold, G., Quenet, B., Cornuet, J.-M., Masson, C., Deschepper, B., Estoup, A. \& Gasquil, P. (1996). Kin recognition in honeybees. Nature, 379: 498.

Bagnères, A. G., Killian, A., Clément, J. L., Lange, C. (1991). Interspecific recognition among termites of the genus Reticulitermes: Evidence for a role for the cuticular hydrocarbons. Journal of Chemical Ecology, 17: 2397-2420.

Bonavita-Cougourdan, A., Clément, J. L., Lange, C. (1987). Nestmate recognition: the role of cuticular hydrocarbons in the ant Camponotus vagus Scop. Journal of Entomological Science, 22:1-10.

Bonavita-Cougourdan, A., Theraulaz, G., Bagnères, A.G., Roux, M., Pratte, M., Provost, E., Clément, J.-L. (1991). Cuticular hydrocarbons, social organization and ovarian development in a polistine wasp: Polistes dominulus. Christ. Comparative Biochemistry and Physiology, 100B: 667-680.

Breed, M. D. (1998). Recognition pheromones of the honey bee. Bioscience, 48: 463-470.

Breed, M. D., Stiller, T. M. (1992). Honey bee, Apis mellifera, nestmate discrimination: hydrocarbon effect and the evolutionary implications of comb choice. Animal Behaviour, 43:875-883.

Breed, M. D., Garry, M. F., Pearce, A. N., Hibbard, B. E., Bjostad, L. B., Page, R. E. (1995). The role of wax comb in honey bee nestmate recognition. Animal Behaviour, 50: 489-496.

Breed, M. D., Leger, S., Pearce, A. N., Wang, Y. J. (1998). Comb wax effects on the ontogeny of honey bee nestmate recognition. Animal Behaviour, 55: 13-20.

Dani, F. R., Jones, G. R., Corsi, S., Beard, R., Pradella, D., Turillazzi, S. (2005). Nestmate recognition cues in the honey bee: differential importance of cuticular alkanes and alkenes. Chemical Senses, 30:477-489.

Bruschini, C., Cervo, R., Cini, A., Pieraccini, G., Pontieri, L., Signorotti, L, Turillazzi, S. (2011). Cuticular Hydrocarbons Rather Than Peptides Are Responsible for Nestmate Recognition in Polistes dominulus. Chemical Senses 36: 715-723.

Carpenter, J.M. (1993). Biogeographic Patterns in Vespidae (Hymenoptera): two Views of Africa and South America. In P. Goldblatt (Ed.) Biological relationships between Africa and South America (p.139-155). New Haven: Yale University Press.

Cervo, R., Dani, F.R. \& Turillazzi, S. (1996). Nestmate recognition in three species of stenogastrinae wasps (Hymenoptera, Vespidae). Behavioral Ecology and Sociobiology, 39: 311-316.

Cervo, R., Dani, F.R., Zanetti, P., Massolo, A. \& Turillazzi, S. (2002). Chemical nestmate recognition in a stenogastrinae wasp, Liostenogaster flavolineata (Hymenoptera, Vespidae). 
Ethology, Ecology and Evolution, 14: 351-363. doi: $10.1080 / 08927014.2002 .9522736$

Dani, F.R., Jones, G.R., Destri, S., Spencer, S.H. \& Turillazzi, S. (2001). Deciphering the recognition signature within the cuticular chemical profile of paper wasps. Animal Behaviour, 62: 165-171. doi: 10.1006/anbe.2001.1714

Espelie, K.E. \& Hermann, H.R. (1990). Surface lipids of the social wasp Polistes annularis (L.) and its nest and nest pedicel. Journal of Chemical Ecology, 16: 1841-1852.

Ferreira, A., Cardoso, C., Neves, E., Súarez, Y., AntonialliJunior, W. (2012). Distinct linear hydrocarbon profiles and chemical strategy of facultative parasitism among Mischocyttarus wasps. Genetics and Molecular Research 11: 4351-4359. doi: 10.4238/2012.September.25.3.

Gamboa, G.J., Grudzien, T.A., Espelie, K.E. \& Bura, E.A. (1996). Kin recognition pheromones in social wasps: combining chemical and behavioural evidence. Animal Behaviour, 51: 625629 .

Hadley, N. F. (1981). Cuticular lipids of terrestrial plants and arthropods: a comparison of their structure, composition, and waterproofing function. Biological Reviews, 56: 23-47.

Haverty, M. I. \& Thorne, B. L. (1989). Agonistic behavior correlated with hydrocarbon phenotypes in dampwood termites, Zootermopsis (Isoptera: Termopsidae). Journal of Insect Behavior, 2: 523-543.

Howard, R.W. \& Blomquist, G.J. (2005). Ecological, behavioral, and biochemical aspects of insect hydrocarbons. Annual Review of Entomology, 50: 371-393. doi: 10.1146/annurev. ento.50.071803.130359

Kaib, M., Franke, S., Francke, W.\& Brandi, R. (2002).Cuticular hydrocarbons in a termite: phenotypes and a neighbourstranger effect. Physiological Entomology, 27(3):189-198. doi: $10.1046 / \mathrm{j} .1365-3032.2002 .00292 . x$

Kaib, M. Jmhasly, P., Wilfert, L., Durka, W., Franke, S., Francke, W., Leuthold, R. H. \& Brandl, R. (2004). Cuticular Hydrocarbons and Aggression in the Termite Macrotermes Subhyalinus. Journal of Chemical Ecology, 30: 365-385. doi: 10.1023/B:JOEC.0000017983.89279.c5

Kather, R., Drijfhout, F. P. \& Martin, S. J. (2011). Task group diffenrences in cuticular lipids in the honey bee Apis mellifera. Journal of Chemical Ecology, 37: 205-212. doi: 10.1007/ s10886-011-9909-4.

Layton, J. M., Camann, M. A. \& Espelie, K. E. (1994). Cuticular lipid profiles of queens, workers and males of social wasp Polistes metricus Say are colony-specific. Journal Chemical Ecology, 20: 2307-2321.

Lockey, K. H. (1988). Lipids of the insect cuticle: origin, composition and function. Comparative Biochemistry and Physiology B, 89: 595-645.

Lorenzi, M.C., Bagnères, A.G., Clément, J.-L. \& Turillazzi, S.
(1997). Polistes biglumis bimaculatus epicuticular hydrocarbons and nestmate recognition (Hymenoptera, Vespidae). Insectes Sociaux, 44: 123-138.

Lorenzi, M.C., Sledge, M.F., Laiolo, P., Sturlini, E. \& Turillazzi, S. (2004). Cuticular hydrocarbon dynamics in young adult Polistes dominulus (Hymenoptera, Vespidae) and the role of linear hydrocarbons in nestmate recognition systems. Journal of Insect Physiology, 50: 935-941. doi: 10.1016/j. jinsphys.2004.07.005.

Mitra, A., Ramachandran, A. \& Gadagkar, R. (2014). Nestmate discrimination in the social wasp Ropalidia marginata: chemical cues and chemosensory mechanism. Animal Behaviour, 88: 113-124. doi: 10.1016/j.anbehav.2013.11.017

Murakami, A.S.N. \& Shima, S.N. (2009). Queen replacement in Mischocyttarus (Monocyttarus) cassununga (Hymenoptera, Vespidae, Mischocyttarini): a particular case. Sociobiology, 53: 247-257.

Murakami, A.S.N. \& Shima, S.N. (2010). Regulation of social hierarchy over time in colonies of the primitive eusocial wasp Mischocyttarus (Monocyttarus) cassununga. Von Ihering, 1903 (Hymenoptera, Vespidae). Journal of the Kansas Entomological Society, 83: 163-171. doi: 10.2317/ JKES0712.04.1

Neves, E., Andrade, L., Súarez, Y., Lima, S. \& AntonialliJunior, W. (2012). Age-related changes in the surface pheromones of the wasp Mischocyttarus consimilis (Hymenoptera: Vespidae). Genetics and Molecular Research 11: 1891-1898. doi: 10.4238/2012.July.19.8.

Nunes, T. M., Nascimento, F. S., Turatti, I. C., Lopes, N. P. \& Zucchi, R. (2008). Nestmate recognition in a stingless bee: does the similarity of chemical cues determine guard acceptance? Animal Behaviour, 75: 1165-1171.

Nunes. T. M., Turatti, I. C. C., Mateus, S., Nascimento, F. S., Lopes, N. P. \& Zucchi, R. (2009). Cuticular hydrocarbons in the stingless bee Schwarziana quadripunctata (Hymenoptera, Apidae, Meliponini): differences between colonies, castes and age. Genetics and Molecular Research, 8: 589-595.

Nunes, T. M., Mateus, S., Turatti, I. C., Morgan, E. D. \& Zucchi, R. (2011). Nestmate recognition in the stingless bee Frieseomelitta varia (Hymenoptera, Apidae, Meliponini): sources of chemical signals. Animal Behaviour, 81: 463-467.

Page, R.E.Jr., Metcalf, R.A., Metcalf, R.L., Erickson, E.H.Jr. \& Lampman, R.L. (1991). Extractable hydrocarbons and kin recognition in honeybee (Apis mellifera L.). Journal of Chemical Ecology, 17: 745-756.

Panek, L.M., Gamboa, G.J. \& Espelie, K.E. (2001). The effect of a wasp's age on its cuticular hydrocarbon profile and its tolerance by nestmate and non-nestmate conspecifics (Polistes fuscatus, Hymenoptera: Vespidae). Ethology, 107: 55-63. doi: 10.1046/j.1439-0310.2001.00633.x 
Pfennig, D.W., Reeve, H. K. \& Shellman, J.S. (1983). Learned component of nestmate discrimination in workers of a social wasp, Polistes fuscatus (Hymenoptera: Vespidae). Animal Behaviour, 31: 412-416.

Pickett, K.M., Mchenry, A. \& Wenzel, J.W. (2000). Nestmate recognition in the absence of a pheromone. Insectes Sociaux, 47: 212-219. doi: 10.1007/PL00001705

Provost, E., Blight, O., Tirard, A. \& Renucci, M. (2008). Insect Physiology: New Research. [Hydrocarbons and Insects' Social Physiology, pp.19-72] Retrived from: http://www. imep-cnrs.com/ibbc/pdf/provost $\% 20$ et $\% 20$ al.insect $\% 20$ physiology.new\%20research.pdf

Ratnieks, F.L.W. (1991). The evolution of genetic odor-cue diversity in social hymenoptera. American Naturalist, 137: 202-226.

Richard, F.-J. \& Hunt, J. H. (2013). Intracolony chemical communication in social insects. Insectes Sociaux, 60: 275291. doi: 10.1007/s00040-013-0306-6

Silveira, O.T. (2008). Phylogeny of wasps of the genus Mischocyttarus de Saussure (Hymenoptera, Vespidae, Polistinae). Revista Brasileira de Entomologia, 52: 510-549. doi: 10.1590/ S0085-56262008000400004

Singer, T.L. (1998). Roles of hydrocarbons in the recognition systems of insects. American Zoologist, 38: 394-405.

Singer, T.L. \& Espelie, K.E. (1997). Exposure to nest paper hydrocarbons is important for nest recognition by a social wasp, Polistes metricus Say (Hymenoptera, Vespidae). Insectes Sociaux, 44: 245-254.

Sturgis, S. J. \& Gordon, D. M. (2011). Nestmate recognition in ants (Hymenoptera: Formicidae): a review. Myrmecological News, 16: 101-110. Retrived from: http://web.stanford. edu/ dmgordon/old2/SturgisGordon2012.pdf

Sumana, A., Liebert, A.E., Berry, A.S., Switz, G.T., Orians, C.M. \& Starks, P.T. (2005). Nest hydrocarbons as cue for philopatry in a paper wasp. Ethology, 111: 469-477. doi: 10.1111/j.14390310.2005.01072.x

Tannure-Nascimento, I.C., Nascimento, F.S., Turatti, I.C., Lopes, N.P., Trigo, J.R. \& Zucchi, R. (2007). Colony membership is reflected by variations in cuticular hydrocarbon profile in a Neotropical paper wasp, Polistes satan (Hymenoptera, Vespidae). Genetics and Molecular Research, 6: 390-396. Retrived from: http://www.geneticsmr.com/articles/365

Tannure-Nascimento, I.C., Nascimento, F.S. \& Zucchi, R. (2008). The look of royalty: visual and odour signals of reproductive status in a paper wasp. Proceedings of the Royal Society B, 11: 1-8. doi: 10.1098/rspb.2008.0589

Vander Meer, R. K., Saliwanchik, D. \& Lavine, B. (1989). Temporal changes in colony cuticular hydrocarbon patterns of Solenopsis invicta: Implications for nestmate recognition. Journal of Chemical Ecology, 15: 2115-2125.

Wagner, D., Tissot, M., Cuevas, W. \& Gordon, D. M. (2000). Harvester ants utilize cuticular hydrocarbons in nestmate recognition. Journal of Chemical Ecology, 26: 2245-2257.

Wilgenburg, E. V., Symonds, M. R. E. \& Elgar, M. A. (2011). Evolution of cuticular hydrocarbon diversity in ants. Journal of Evolutionary Biology, 24: 1188-1198. doi: 10.1111/j.14209101.2011.02248.x.

Zanetti, P., Dani, F.R., Destri, S., Fanelli, D., Massolo, A., Moneti, G., Pieraccini \& G.E Turillazzi, S. (2001). Nestmate recognition in Parischnogaster striatula (Hymenoptera, Stenogastrinae), visual and olfactory recognition cues. Journal of Insect Physiology, 47 : 1013-1020. doi: 10.1016/S0022-1910(01)00077-4 